\title{
LOGISTICS 4.0: SMART INFRASTRUCTURE
}

\author{
Elke Glistau \\ associate professor, Otto von Guericke University Magdeburg, Germany \\ 39106 Magdeburg Universitätsplatz 2,e-mail: elke.glistau@ovgu.de \\ Sebastian Trojahn \\ associate professor, Anhalt University of Applied Sciences Bernburg, Germany \\ Otto von Guericke University Magdeburg, Germany \\ 39106 Magdeburg Universitätsplatz 2, e-mail: sebastian.trojahn@ovgu.de \\ Ágota Bányainé Tóth \\ associate professor, University Miskolc, Hungary \\ 3515 Miskolc, Miskolc-Egyetemváros, e-mail: altagota@uni-miskolc.hu
}

\begin{abstract}
The theoretical foundations of Logistics 4.0 are being researched at the OVG University of Magdeburg and the University of Miskolc. The model of the Smart Logistics Zone, which was jointly developed in Magdeburg by the Fraunhofer Institute IFF and Otto von Guericke University at ILM, can be used to describe logistics solutions. At its core, it differentiates between logistical objects, logistical processes, logistical systems and logistical infrastructure. The logistical infrastructure is currently gaining great importance. In the article, some important basics of infrastructure planning and current trends and developments are considered. The objectives are to characterise infrastructure holistically, to define new developments and to pose current research questions related to infrastructure.
\end{abstract}

Keywords: Logistics 4.0, Smart Logistics Zone, smart infrastructure

\section{Introduction}

Physical infrastructures are currently coming more into focus in politics, business and the media. This is supported by major investments worth billions, such as in the new Silk Road and the US infrastructure programme. In the scientific world of logistics, on the other hand, infrastructure has so far tended to lead a shadowy existence. This article is dedicated to the infrastructures used by logistics. Based on the analysis of current literature and own empirical knowledge, a scientific analysis of logistics infrastructure will be conducted, with a focus on smart infrastructure. The literature analysis is deliberately carried out primarily on the World Wide Web, as many infrastructure measures are published in political programmes, daily news and popular science articles. The goals of the scientific investigation are to record and systematise the existing knowledge in the field of logistics infrastructure and to derive recommendations for actin for the logistician. 


\section{Smart Infrastructure: goals, term and relationship to Smart Logistics Zone}

First, the question of how a smart infrastructure is defined and what all belongs to a smart infrastructure is clarified. For a better understanding of the term, a smart infrastructure will be characterised in the following.

Current trends and developments form the starting point. Two major trends are Industry 4.0 and sustainability. They allow properties as well as target and evaluation variables to be derived, such as digitalisation and networking, economy, ecology and social aspects. Many current infrastructure measures such as the preparation of $5 \mathrm{G}$ and the modernisation of the rail network can be classified here. As a cause of and affected by climate change, logistics also has major tasks ahead of it, especially in the area of infrastructure. Other important current objectives and thus also evaluation parameters relate to resilience, reliability and security.

Infrastructure is a "system of facilities, equipment and services necessary for the operation of an organisation" (DIN EN ISO 9000, 2015). In the logistics context, infrastructures are to be understood as a required necessity and basis for the performance of logistics services. The logistics infrastructure fulfils basic tasks of energy, information and material supply and disposal. Infrastructure are "the basic physical and organizational structures and facilities (e.g. buildings, roads, power supplies) needed for the operation of a society or enterprise". (Stevenson \& Waite, 2011) Simply speaking, "Infrastructure" means those basic facilities and services which facilitates different economic activities and thereby help in economic development of the country, education, health, transport and communication, banking and insurance, irrigation and power and science and technology etc. are the examples of infrastructure. These are also called social over head capital. These do not directly produce goods and services but induce production in agriculture, industry and trade by generating external economies (w.A., 2020). As society moves deeper into the twenty-first century, the societal demand on infrastructure assets is growing rapidly, with high expectations in terms of productivity and service delivery (Annaswamy, 2016). Table 1 first explains the term infrastructure.

Table 1. Term Infrastructure (Jochimsen, 1966) (Benedict et al., 2002)

\begin{tabular}{|c|c|c|}
\hline Technical Infrastructure & Social Infrastructure & Green/blue Infrastructure \\
\hline $\begin{array}{l}\text { Transport infrastructure: } \\
\text { roads, railway lines, ship- } \\
\text { ping routes, air traffic }\end{array}$ & Education system & \multirow{5}{*}{$\begin{array}{l}\text { Interconnected network of } \\
\text { waterways, wetlands, } \\
\text { woodlands, wildlife habitats } \\
\text { and other natural areas; gre- } \\
\text { enways, parks and other } \\
\text { conservation lands; ranches } \\
\text { and forests; and wilderness } \\
\text { and other open spaces that } \\
\text { support native species, main- } \\
\text { tain natural ecological pro- } \\
\text { cesses, sustain air and water } \\
\text { resources and contribute to } \\
\text { the health and quality of life }\end{array}$} \\
\hline Energy and water supply & Healthcare system & \\
\hline $\begin{array}{l}\text { Disposal facilities for was- } \\
\text { te water, waste disposal, } \\
\text { recycling }\end{array}$ & Justice and prisons & \\
\hline \multirow[b]{2}{*}{$\begin{array}{l}\text { Digital Infrastructure \& } \\
\text { communication }\end{array}$} & $\begin{array}{l}\text { Nursing homes for the sick and } \\
\text { elderly }\end{array}$ & \\
\hline & Public administrations & \\
\hline
\end{tabular}

This quest for more efficient infrastructure associated with the rise of information technology (IT) has led to the concept of „smart infrastructure”, wherein enabling technologies such as connected sen- 
sors and big data analytics are integrated with physical infrastructure in order to achieve real-time monitoring, efficient decision-making and enhanced service delivery (Weiss, 2009).

The potential benefits of smart infrastructure include decreased maintenance costs, reduced damage and disruption costs (i.e. traffic congestion or power blackout), increased quality and value of service (i.e. on-demand use and flexible tariffs), as well as protecting human life (i.e. better response to disasters) (Morimoto, 2010).

The intelligence of the infrastructure can be described by the following properties (Compare Müller et al., 2017):

- Integrated functions for identification, localisation and diagnosis of internal parameters,

- Ability to recognise physical conditions and measure outcomes (e.g. performance),

- Ability to process data to identify relevant information,

- Ability to interact with other smart objects and central information systems,

- Standardisation with uniform protocols.

Figure 1 shows how the smart infrastructure fits into the model of the Smart Logistics Zone. A smart logistics solution can always be characterised on the basis of the eight aspects mentioned: Initially, it does not matter in which areas the intelligence lies. The goal is to create logistics solutions whose intelligence corresponds to the requirements of the overall solution. Thus intelligence is not an end in itself, but is derived from the concrete customer requirements. The logistics infrastructure forms the basis for smart logistics objects, systems and processes. Only their interaction enables the implementation of the logistics service.

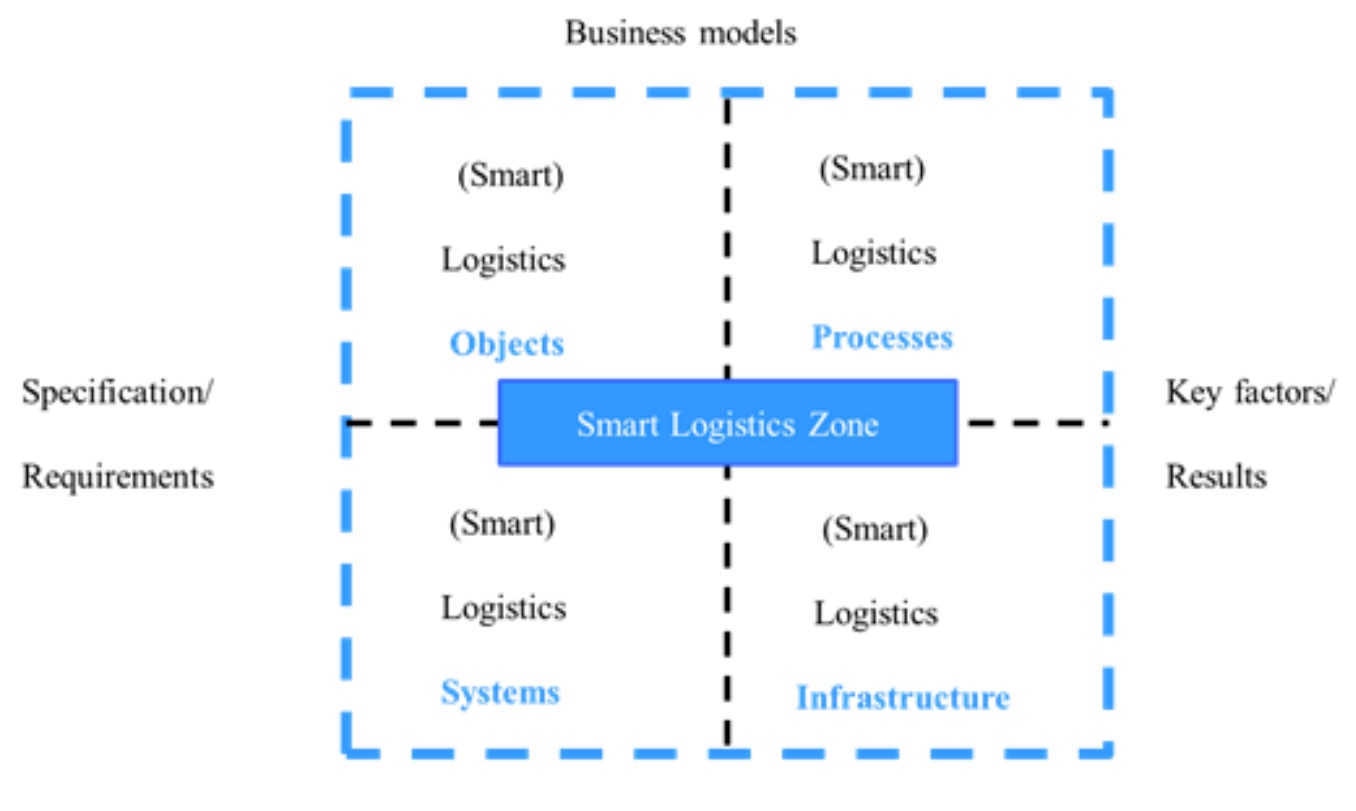

Technological basics

Figure 1. Smart infrastructure in the Smart Logistics Zone model (Glistau,2020)

First, the classic infrastructure objects (cf. Table 2) will be named as examples before the smart logistics infrastructure is characterised. 
Table 2. Examples of "hard" infrastructure objects of the technical infrastructure

\begin{tabular}{|c|c|c|}
\hline \multicolumn{2}{|c|}{ Infrastructure objects of the } & Examples of "hard" infrastructure objects \\
\hline \multirow{7}{*}{ 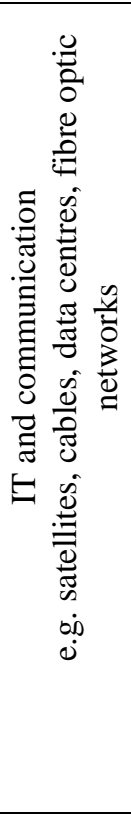 } & Road traffic & $\begin{array}{l}\text { Roads including motorways, bridges, tunnels, intersections, traffic } \\
\text { lights, street lamps, traffic signs, traffic guidance systems, level } \\
\text { crossings, roundabouts, car parks, rest areas, bus stops, ferries, toll } \\
\text { stations, loading and unloading ramps, petrol stations and electric } \\
\text { charging points, freight transport centres }\end{array}$ \\
\hline & Rail transport & $\begin{array}{c}\text { Tracks, signal boxes, stations, bridges, tunnels, railway parks, loco- } \\
\text { motive sheds, turntables, marshalling yards, repair workshops, } \\
\text { railway depots, points, control and safety technology and crane } \\
\text { systems }\end{array}$ \\
\hline & Water traffic & $\begin{array}{l}\text { Waterways, ship lifts, locks, lighthouses, marinas, ports, natural har- } \\
\text { bours, canal bridges, sea bridges, ship tunnels, quays and wharves }\end{array}$ \\
\hline & Air traffic & $\begin{array}{l}\text { Runways, towers, hangars, airport terminals, air cargo terminals, pas- } \\
\text { senger transport systems and baggage handling systems }\end{array}$ \\
\hline & Energy supply & Electricity grid, gas grid and compressor stations \\
\hline & Disposal & $\begin{array}{l}\text { Infrastructure of disposal technology including preparation for reuse, } \\
\text { recycling, other (material and energy) recovery, disposal }\end{array}$ \\
\hline & Water supply & $\begin{array}{l}\text { Wells, pumps, water pipes and *waste water pipes (see also disposal), } \\
\text { infrastructure of water supply companies and water treatment com- } \\
\text { panies }\end{array}$ \\
\hline
\end{tabular}

In addition to the "hard" infrastructure components, there are also "soft" infrastructure components such as road traffic regulations, infrastructure management and infrastructure administration. (Cf. Infrastructure, 2019) The term institutional infrastructure includes the legal order, the social order and the economic order. In the context of logistical spaces and the impact of Industry 4.0 / Logistics 4.0, digital and smart as well as transport, energy and communication infrastructures are of particularly high relevance (compare Krampe et al., 2012).

The digital, also called information technology infrastructure (cf. Table 2) has a cross-sectional function and includes the technical information and communication systems for handling digital data. These include, for example, data centres and data transmission paths such as cables, satellites or radio frequencies. They are the basis of the technical communication infrastructure. They include mobile radio and fibre optic networks, routers for public WLAN as well as servers and IP addresses. Communication protocols define in which form, speed and quality data is transmitted and repair mechanisms are carried out (compare Geisberger \& Broy, 2012) (Obermann \& Weiß, 2016).

The term transport infrastructure refers to transport routes (e.g. road and rail networks), -stations (e.g. freight transport centres) and facilities (e.g. traffic lights) (cf. Table 2), (compare Malina, 2018). It enables the logistical flow of people and goods by means of the various means of transport (e.g. buses, trucks, conveyors) and thus represents the basis of logistics services. The same applies to the other modes of transport.

There is little general clarification of the term "smart infrastructure" in the scientific literature. Schenk characterises the infrastructure within Smart Logistics Spaces as "logistical infrastructure with an IT-technical ambient intelligence". (Schenk, 2015) Geisberger and Broy define smart infrastructures as a further developed digital infrastructure equipped with smart sensor and actuator technology for monitoring and controlling networked logistics processes. (Compare Geisberger \& Broy 2012) 
The literature distinguishes between four development stages of smart infrastructures: descriptive, prescriptive, predictive and plan-full (Compare Mynatt et al. 2017). This means with descriptive: the infrastructure detects traffic congestion, with prescriptive: the infrastructure offers an alternative route, with predictive: the infrastructure plans a route based on weather- and time-of-day-dependent patterns and with plan-full: the infrastructure takes over traffic control based on real-time information. (Compare Mynatt et al., 2017)

In order to describe the smart infrastructure on the basis of its characteristics in a morphological box, the following characteristics were used: Functionality, identification, localisation, sensors, data and information processing, data transmission technology, networking, command and control, actuators, cooperation technology and the type of software interface.

This newly developed morphology of smart infrastructure serves to characterise existing smart infrastructure and opens up options for the further development of infrastructures and their properties. Table 3 shows a small excerpt from the developed morphology.

Table 3. Excerpt of a morphology for the definition of smart infrastructures (Compare Lange, 2020)

\begin{tabular}{|c|c|c|c|c|c|c|c|c|c|}
\hline \multirow{2}{*}{\multicolumn{2}{|c|}{$\begin{array}{l}\text { Feature } \\
\text { Functiona- } \\
\text { lity }\end{array}$}} & \multicolumn{8}{|c|}{ Characteristic property } \\
\hline & & $\begin{array}{l}\text { Identi- } \\
\text { fication }\end{array}$ & $\begin{array}{l}\text { Locali- } \\
\text { sation }\end{array}$ & $\begin{array}{l}\text { Data } \\
\text { collection }\end{array}$ & $\begin{array}{l}\text { Data- } \\
\text { proces- } \\
\text { sing }\end{array}$ & $\begin{array}{l}\text { Data } \\
\text { storage }\end{array}$ & $\begin{array}{l}\text { Communi- } \\
\text { cation } \\
\text { skills } \\
\end{array}$ & $\begin{array}{l}\text { Making } \\
\text { decisions }\end{array}$ & $\ldots$ \\
\hline \multicolumn{2}{|l|}{$\ldots$} & & & & & & & & $\ldots$ \\
\hline \multirow[b]{3}{*}{ 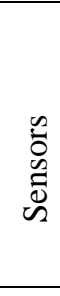 } & $\begin{array}{l}\text { Func- } \\
\text { tion }\end{array}$ & \multicolumn{2}{|l|}{ none } & $\begin{array}{l}\text { Identi- } \\
\text { cation }\end{array}$ & \multicolumn{2}{|c|}{$\begin{array}{l}\text { Integrated smart } \\
\text { sensor }\end{array}$} & \multicolumn{3}{|c|}{ Wireless sensor network } \\
\hline & Meas- & \multicolumn{6}{|l|}{ Physical } & \multicolumn{2}{|l|}{ Chemical } \\
\hline & $\begin{array}{l}\text { ured } \\
\text { vari- } \\
\text { able }\end{array}$ & $\begin{array}{l}\text { Tempe- } \\
\text { rature }\end{array}$ & Power & Humidity & $\begin{array}{l}\text { Surroun- } \\
\text { dings }\end{array}$ & $\begin{array}{l}\text { Object } \\
\text { identi- } \\
\text { fi- } \\
\text { cation }\end{array}$ & Other & $\begin{array}{l}\text { Concen- } \\
\text { tration }\end{array}$ & $\ldots$ \\
\hline$\cdots$ & & & & & & & & & $\cdots$ \\
\hline
\end{tabular}

\section{Success stories of smart infrastructure}

In the following, some examples of smart infrastructure will be named and characterised. Smart infrastructure solutions reduce energy consumption and energy costs. They help to reduce traffic-related emissions and enable the careful use of resources. Examples include streetlights that only light up when vehicles or people approach, or charging stations for company cars that optimise themselves automatically. On the other hand, they contribute to increasing road safety, traffic efficiency, enabling autonomous driving or supporting maintenance. Table 4 lists some success stories of smart infrastructure. This explicitly includes BIM (Building Information Modelling) as a digital data basis for infrastructure construction. 
Table 4. Some success stories of smart infrastructure

\begin{tabular}{|c|c|c|}
\hline Success story & Content & Application \\
\hline $\begin{array}{l}\text { Telematics solutions } \\
\text { by using vehicle-to- } \\
\text { everything } \\
\text { (V2X) } \\
\text { [19] [20] }\end{array}$ & $\begin{array}{l}\text { Include vehicle-to-vehicle } \\
\text { (V2V), vehicle-to- } \\
\text { infrastructure (V2I) and ve- } \\
\text { hicle-to-pedestrian (V2P) } \\
\text { communication, } \\
\text { Early warning of disrup- } \\
\text { tions on the route }\end{array}$ & $\begin{array}{c}\text { Collision warning, } \\
\text { Construction site warning, } \\
\text { Emergency vehicle detector, } \\
\text { Column formation, Inter- } \\
\text { section assistant }\end{array}$ \\
\hline $\begin{array}{l}\text { Smart motorway } \\
{[21]}\end{array}$ & $\begin{array}{l}\text { Sensors record position, speed, } \\
\text { direction of movement, } \\
\text { Digital image of reality }\end{array}$ & $\begin{array}{l}\text { Looking ahead to route, inc- } \\
\text { reasing traffic density }\end{array}$ \\
\hline Smart crossing [22] & $\begin{array}{c}\text { Sensor network enables } \\
\text { transmission of a } 360 \text {-degree } \\
\text { model to road users }\end{array}$ & $\begin{array}{c}\text { Increase road safety at blind } \\
\text { intersections }\end{array}$ \\
\hline $\begin{array}{c}\text { Smart street lamp } \\
\text { [23] [24] }\end{array}$ & $\begin{array}{l}\text { Regulation of lighting according } \\
\text { to the number of users in the } \\
\text { area, natural lighting and special } \\
\text { weather conditions }\end{array}$ & Reduce energy costs \\
\hline $\begin{array}{l}\text { Smart bridge } \\
{[25][26]}\end{array}$ & $\begin{array}{l}\text { Detection of strain, vibration, } \\
\text { inclination, humidity, } \mathrm{pH} \text { value, } \\
\text { temperature }\end{array}$ & $\begin{array}{c}\text { Provide information on po- } \\
\text { tential material weaknesses } \\
\text { for targeted, preventive } \\
\text { maintenance. }\end{array}$ \\
\hline $\begin{array}{c}\text { SAFARI digital test } \\
\text { field } \\
{[27][28]} \\
\text { and projects for the } \\
\text { use of automated ve- } \\
\text { hicles }\end{array}$ & $\begin{array}{l}\text { Self-updating HD maps as a } \\
\text { basis for automated driving, } \\
\text { sensory environmental un- } \\
\text { derstanding and localisation of } \\
\text { automated vehicles, } \\
\text { Communicating road infra- } \\
\text { structure, } \\
\text { Identification of temporary } \\
\text { events (e.g. road works), } \\
\text { Use of automated vehicles as } \\
\text { local public transport }\end{array}$ & $\begin{array}{l}\text { Test fields and projects for } \\
\text { urban transport }\end{array}$ \\
\hline $\begin{array}{c}\text { Smart airlock } \\
\text { [29] }\end{array}$ & $\begin{array}{l}\text { Information on water level, use } \\
\text { high water level to fill sluice } \\
\text { with as little energy as possible }\end{array}$ & $\begin{array}{c}\text { Reduction of energy expen- } \\
\text { diture }\end{array}$ \\
\hline $\begin{array}{c}\text { New Silk Road } \\
{[30]}\end{array}$ & $\begin{array}{l}\text { Differentiated into land route } \\
\text { "Silk Road Economic Belt" and } \\
\text { sea route "Maritime Silk Road". }\end{array}$ & $\begin{array}{l}\text { Planned to connect more } \\
\text { than } 60 \text { countries and thus } \\
\text { two thirds of the world's } \\
\text { population }\end{array}$ \\
\hline $\begin{array}{l}\text { Smart Grid } \\
{[31][32]}\end{array}$ & $\begin{array}{l}\text { Refers to an smart power grid, } \\
\text { within which information is } \\
\text { exchanged for the dynamic cont- } \\
\text { rol of power generation, con- } \\
\text { sumption and storage. }\end{array}$ & $\begin{array}{l}\text { Realisation of temporally } \\
\text { and spatially homogeneous } \\
\text { power consumption through } \\
\text { better integration of inho- } \\
\text { mogeneous power genera- } \\
\text { tors. }\end{array}$ \\
\hline
\end{tabular}




\section{Tasks for the logistician to plan a smart infrastructure}

Policymakers (BMVI in Germany) are drawing up their own packages of measures in relation to digitalisation and $\mathrm{AI}$ in mobility, for example, and defining fields of action that include the following:

- Expansion of an efficient, digital infrastructure,

- Equipping the transport structure with the necessary digital technology,

- Creation of a comprehensive and reliable data basis,

- Promotion of innovative technologies and their regulation for the automation and networking of vehicles, processes and services for all transport modes and

- Networking of measures and actors across transport modes in the overall system. (BMVI, 2021)

For the logistician, the following tasks arise for planning a smart infrastructure:

- Plan logistical requirements for the infrastructure,

- Planning the concrete infrastructure,

- Further development of infrastructure solutions,

- Research and evaluate relevant new infrastructure solutions,

- Transferring infrastructure solutions into implementation,

- Securing critical infrastructure,

- Connecting infrastructure, logistics object and logistics system into a smart overall solution (Smart Logistics Zone).

\section{Research tasks/questions for the future in the thematic field of logistical smart infra- structure}

The literature review revealed some gaps in the research, which will be illustrated with research tasks and questions. They provide starting points for a scientific discourse. As examples, some of them will be mentioned that are already being discussed or are in progress (cf. BVL, 2021), (Sucky \& Haas, 2021):

(1) Which scenarios are conceivable in order to be able to install a nationwide, smart infrastructure in Germany/Europe/the world?

(2) How should the charging infrastructure in cities/regions/nationally be planned for individual means of transport (e.g. for e-cars or for cargo bikes)?

(3) What does a nationwide infrastructure for hydrogen look like? What are the specific requirements?

(4) What intelligence should be transferred to the infrastructure for autonomous driving?

(5) How do climate change and other influences affect critical infrastructure?

(6) What is the role of sustainability in smart infrastructure?

(7) What are the drivers for implementing smart infrastructure? How are the responsibilities divided?

(8) What are the benefits of deploying 5G for smart infrastructure?

(9) How are the target variables of logistics changing? What impact does this have on the infrastructure?

(10) What new technologies are needed to realise an smart logistics infrastructure? Can existing systems be upgraded to meet new requirements? 


\section{Summary}

The logistics infrastructure is part of the logistics solution. In the scientific world of logistics, it has so far led a shadowy existence. In the article, the terms infrastructure and smart infrastructure are defined under a logistics focus.

The (smart) logistics infrastructure is placed in the model of the Smart Logistics Zonee to describe Logistics 4.0 solutions. To show possible solutions, examples of new infrastructure solutions are named and briefly explained. The tasks of the logistician for planning the infrastructure are derived from the solutions. The article names exemplary research tasks and questions for the future in the subject area of logistics infrastructure.

\section{References}

[1] DIN EN ISO 9000:2015-11. Quality management systems - Fundamentals and vocabulary (ISO 9000:2015). German and English version EN ISO 9000:2015. p. 36

[2] Stevenson, A., Waite, M. (2011). Concise Oxford English Dictionary. 12th revised edition

[3] Meaning, Types and Development of Economic Infrastructure in India http://www.economicsdiscussion.net/economics-2/meaning-types-and-development-ofeconomic-infrastructure-in-india-2/2174. (2020), last checked 15.07.21.

[4] Annaswamy, A. M., Malekpour, A. R., Baros, S. (2016). Emerging research topics in control for smart infrastructures. Annual Reviews in Control, 42, 259-270. https://doi.org/10.1016/j.arcontrol.2016.10.001

[5] Jochimsen, R. (1966). Theorie der Infrastruktur. Grundlagen der marktwirtschaftlichen Entwicklung. Tübingen, Mohr (Siebeck)

[6] Benedict, M. A., McMahon, E. T. (2002). Green Infrastructure: Smart Conservation for the 21st Century. Renewable Resources Journal, 12-17.

[7] Weiss, A. (2009). Smart infrastructure matches supply and demand. Networker, 13(3), 18-25. https://doi.org/10.1145/1600303.1600309

[8] Morimoto, R. (2010). Estimating the benefits of effectively and proactively maintaining infrastructure with the innovative smart infrastructure sensor system. Socio-economic Planning Sciences, 44(4), 247-257.

[9] Mueller, E., Chen, XL. \& Riedel, R. Chin. J. (2017). Challenges and Requirements for the Application of Industry 4.0: A Special Insight with the Usage of Cyber-Physical System Mech. Eng. https://link.springer.com/article/10.1007/s10033-017-0164-7. last checked on 13.07.2021 https://doi.org/10.1007/s10033-017-0164-7

[10] Glistau, E. (2020). Cover picture In: Schenk, Michael [Publisher]; Glistau, Elke [Publisher] 13th International Doctoral Students Workshop on Logistics, June 16, 2020 Magdeburg

[11] Infrastructure, (2019). http://www.mobi-wissen.de/Verkehr/Infrastruktur. last checked on 13.05.2021

[12] Krampe, H., Lucke, H.-J., Schenk, M. (Ed.) (2012). Grundlagen der Logistik. Einführung in Theorie und Praxis logistischer Systeme. 4. Ed. München: Huss-Publisher. p. 19

[13] Geisberger, E., Broy, M. (2012). agendaCPS - Integrierte Forschungsagenda Cyber-Physical Systems (acatech STUDIE). Berlin, Heidelberg: Springer-Publisher. pp. 247/248 https://doi.org/10.1007/978-3-642-29099-2 
[14] Obermann, R., Weiß, M. (2016). Digitale Infrastruktur als Basis für einen optimalen Informationsfluss. In: Bär, C. et al., Informationstechnologien als Wegbereiter für den steuerberatenden Berufsstand (Bd. 55., pp. 163-177). Berlin, Heidelberg: Springer Berlin Heidelberg. https://doi.org/10.1007/978-3-662-44909-7_17

[15] Malina, R. (2018). Stichwort: Verkehrsinfrastruktur. Published by Gabler Wirtschaftslexikon. Online available https://wirtschaftslexikon.gabler.de/definition/verkehrsinfrastruktur48660/version-271911. last checked on 15.05.2021

[16] Schenk, M. (Hg.) (2015). Produktion und Logistik mit Zukunft: Digital Engineering and Operation. Berlin, Heidelberg: Springer Berlin Heidelberg. p. 249

https://doi.org/10.1007/978-3-662-48266-7

[17] Mynatt, E., Clark, J., Hager, G., Lopresti, D., Morrisett, G., Nahrstedt, K. (2017). A National Research Agenda for Intelligent Infrastructure. Online available unter https://cra.org/ccc/resources/ccc-led-whitepapers/. last checked on 05.03.2020. p. 2

[18] Lange, A. (2020). Konzept zur Gestaltung Cyber-Physischer Logistiksysteme im Kontext des Intelligenten Logistikraums. Otto von Guericke University, MB, ILM, Master thesis. Adviser: Glistau, E., Schmidtke, N., Kutzler, T.

[19] Vehicle to Everything. https://www.itwissen.info/V2X-vehicle-to-everything.html. last checked on 14.07.2021

[20] Vehicle to Everything (V2X). https://www.st.com/en/applications/telematics-andnetworking/vehicle-to-everything-v2x.html. last checked on 15.07.2021

[21] https://www.presseportal.de/pm/108888/3572475. 28.02.2017. last checked on 13.07.2021

[22] https://www.next-mobility.news/wie-intelligente-kreuzungen-smart-cities-sicherer-machen-a672908/. last checked on 09.03.2019

[23] https://www.continental-corporation.com/de/presse/pressemitteilungen/2018-12-17-ces-2019smart-cities-156212

[24] https://www.digitale-vernetzung.org/de/projekte/streets.html . last checked on 13.07.2021

[25] http://buildipedia.com/aec-pros/public-infrastructure/innovative-infrastructure-smart- bridges?print=1\&tmpl=component. last checked on 13.03.2019

[26] https://www.intelligentebruecke.de/ibruecke/DE/Projekte/projekte_node.html. last checked on 13.07.2021

[27] https://www.bmvi.de/SharedDocs/DE/Anlage/Digitales/uebersicht-digitale-testfelder-avfbmvi.pdf?_blob=publicationFile. last checked on 22.05.2019

[28] https://www.bmvi.de/SharedDocs/DE/Artikel/DG/AVF-projekte/safari.html. last checked on 15.07.2021

[29] https://bremenports.de/unternehmen/oslebshauser-schleuse-soll-intelligent-werden/. last checked on 15.07.2021

[30] https://www.gtai.de/gtai-de/trade/specials/digitale-seidenstrasse/digitale-seidenstrasse-europa. last checked on 15.07.2021

[31] https://www.eon.de/de/eonerleben/smart-grid-so-funktioniert-das-intelligente-stromnetz.html. last checked on 15.07.2021 https://doi.org/10.1055/s-0041-1731234

[32] https://www.umweltbundesamt.de/service/uba-fragen/was-ist-ein-smart-grid. last checked on 21.05.2019

[33] https://www.bmvi.de/SharedDocs/DE/Artikel/DG/aktionsplan-kuenstliche-intelligenz.html. last checked on 13.07.2021 
[34] Bundesvereinigung Logistik: Wissenschafticher Beirat der Bundesvereinigung Logistik: Logistik als Wissenschaft - zentrale Forschungsfragen in Zeiten der vierten industriellen Revolution. Verfügbar unter https://www.bvl.de/positionspapier-logistik40. last checked on 13.07.2021

[35] Sucky, E., Haas, S.: Einkauf ,grüner" Logistikleistungen - eine empirische Studie. Bamberg OPUS. https://doi.org/10.20378/irbo-51545. last checked on 13.07.2021 